was a member of a number of academies and learned societies both domestic and foreign.

Almost a year ago I visited him in a hospital and we talked about a book he was preparing, but then I had not the slightest idea that I was never to see him again.

Kazuhiko Nishijima

\section{Gilbert Stead}

Professor STEAD, who died on 5 July 1979 , aged 91 , was one of a small group of physicists who helped to establish radiology as an independent medical discipline.

Medical interest in X-rays was sparked off by a lecture given by Silvanus Thompson to the Clinical Society of London in March, 1896, and during the next 25 years, largely through the enthusiasm of younger doctors with no special training, the use of $\mathrm{X}$-rays for diagnostic purposes spread rapidly. These pioneers often built and maintained their own apparatus!

It was not until the Cambridge Diploma in Medical Radiology and Electrology (D.M.R.E.) was instituted in 1919 that such training became available. A course in radiological physics was begun by J.A. Crowther at the Cavendish Laboratory in 1920, with Rutherford's active support; S. Russ and L.H. Clark provided similar courses in London. In 1924, Stead took over the Cambridge teaching as University Lecturer in Physics as Applied to Medical Radiology and he continued it until 1938. From 1927 until 1942, when this Diploma was discontinued, he was also Secretary to the Diploma Committee.

Stead's connection with Guy's Hospitasl began in 1923 when he was appointed Reader in Physics in the Medical School, a part-time post. The facilities available there only allowed for under-graduate teaching, but in 1938 he was elected by the University of London to a Chair of Physics and was given proper laboratory accommodation. Unfortunately, the outbreak of war in 1939 caused evacuation to Tunbridge Wells and it was not until 1945 that he could begin to build up his department as a centre for applying physics in medicine.

He set up courses for the newer radiological diplomas which had been instituted by the University of London and by the Royal Colleges of Physicians and of Surgeons; and he acted as examiner for them at various times until he retired in 1953 , having contributed greatly to setting the standards of teaching and examination which made these diplomas universally accepted. He was President of the British Institute of Radiology (the original Röntgen Society, founded by a group of medical men in 1897) in 1947/48 and delivered the Silvanus Thompson Memorial Lecture there in 1959. He was Honorary Consulting Physicist to Guy's Hospital and a Governor of the Medical School.

During his 30 years at Guy's Stead established a great reputation as a teacher. Some 3,000 undergraduates (who had to "do" physics in their first year, not always willingly!) attended his courses. Gentle in manner, patient and understanding their difficulties, he succeeded not only in overcoming their foibles but also in winning their affection. A text-book, Elementary Physics, which he wrote with such students in mind, is now (1979) in its eleventh edition; it was first published in 1923!

Stead outlived most of his contemporaries, but many younger people, not only in this country, remember his retiring, courteous personality. $\mathrm{He}$ was once described as "shrewd in discussion, wise in counsel and temperate in judgment." Those who had the privilege of working closely with him knew him also as a loyal friend.

C.B. Allsopp

\section{Carl L. Hubbs}

Professor Carl LeavitT Hubbs, one of the world's most distinguished ichthyologists, doyen of that tribe in America, a true naturalist and a great personality, died on 7 July 1979 at the age of 84 .

Born in Williams, Arizona, shortly after his mother was rescued by a train crew who had found her lost in the desert while driving a wagon, Carl Hubbs ended his distinguished career as Professor Emeritus of the Scripps Institute of Oceanography (University of California) where he had worked since 1944.

The early arousal of his interest in natural history he attributed to his maternal grandmother, one of the first woman physicians; it was further expanded by his father, a self-taught mineralogist, and was fully developed at Stanford University under the rigorous tutelage of that master ichthyologist David Starr Jordan. Hubbs obtained his bachelor's (1916) and master's (1917) degrees at Stanford, and his doctorate (1927) at the University of Michigan. After three years as a curator in the Field Museum, Chicago, he returned, for 24 years, to the University of Michigan. There, apart from his lecturing duties he was curator of vertebrates in the University Museum, and was responsible for building up that museum's collection of fishes, now one of the finest in the world.

Hubb's command of ichthyology was awesome, his research interests extensive but penetrating; their results, published in over 600 papers, could never be criticised for being superficial or trivial. Perhaps the most characteristic feature of his taxonomic work was the way in which he took account of the animal's biology and viewed his subjects in their historical context. It is no wonder that Hubbs contributed so much to unravelling the historical biogeography of American freshwater fishes, nor that his interests should have turned to distributional problems in marine fishes as well. That, in turn, led him into oceanographical and meteorological research, while his freshwater studies took him into the fields of archaeology and human palaeoecology.

With his wife Laura, a mathematician and a dedicated companion, Carl Hubbs pioneered several studies into the genetics of fishes, in particular the application of hybridization studies to the systematics of several taxonomically "difficult" groups. Together they were responsible for discovering the now famous matroclinous and gynogenetic reproduction of the Amazon Molly, Poecilia formosa.

Problems of speciation and evolution, especially amongst the rich freshwater fish faunas of north and middle America, also attracted Hubbs. Interestingly, the phrase "new systematics" was first coined by him several years before it was used, apparently as a neologism, by Huxley as a title for that now classic collection of taxonomic essays he edited in 1940.

Conservation was a long standing concern of Hubbs'. He was instrumental in protecting forests, elk, fur seals, the Pacific gray whale and, after a forcefully conducted fight, the desert pupfish of Devil's Hole, Nevada.

That quite inadequate summary of Carl Hubb's research and influence on World ichthyology has overlooked his role in the development of many American research institutes and professional societies, his importance as a teacher, especially of postgraduate students, and his dedicated involvement in the more pragmatic aspects of his great love, ichthyology.

Many honours were conferred on him, including election to the National Academy of Sciences, the award of the Joseph Leidy Medal, the Shinkishi Hatai Medal of Japan, the sole honorary membership of the Japanese Ichthyological Society, and election to Foreign Niembership of the Linnean Society of London.

Informally Carl Hubbs will long be remembered with warm affection by those who knew him, in particular by fellow ichthyologists for whom, irrespective of their status in the discipline, and despite his many commitments, he could always find time to share his knowledge and give his critical encouragement. Historically his contributions to ichthyology will ensure him a degree of immortality vouchsafed to few.

P.H. Greenwood 